\title{
Core-shell graphene@amorphous carbon composites supported platinum catalysts for oxygen reduction reaction
}

\author{
Hui Wu, Tao Peng, Zongkui Kou, Jian Zhang, Kun Cheng, Daping He, Mu Pan, Shichun Mu* \\ State Key Laboratory of Advanced Technology for Materials Synthesis and Processing, Wuhan University of Technology, Wuhan 430070, Hubei, China
}

\section{A R T I C L E I N F O}

Article history:

Received 12 July 2014

Accepted 22 August 2014

Published 20 April 2015

\section{Keywords:}

Low-temperature fuel cell

Support

Core-shell structure

Oxygen reduction reaction

\begin{abstract}
A B S T R A C T
A core-shell graphene nanosheets (GNS) and amorphous carbon composite (GNS@a-C) was prepared by a chlorination method and used as a highly efficient catalyst support for oxygen reduction reaction. Herein, GNS as a shell, with excellent conductivity, high surface area, and corrosion resistance, served as a protecting coating to alleviate the degradation of amorphous carbon core. Platinum nanoparticles were homogeneously deposited on the carbon support (Pt/GNS@a-C) and showed a good catalytic activity and a higher electrochemical stability when compared with a commercial Pt/C catalyst. The mass activity of Pt/GNS@a-C catalyst was $0.121 \mathrm{~A} / \mathrm{mg}$, which was almost twice as high as that of Pt/C (0.064 A/mg). Moreover, Pt/GNS@a-C retained 51\% of its initial electrochemical specific area after 4000 operating cycles when compared with Pt/C (33\%). Thus, the prepared catalyst featured excellent electrochemical stability, showing promise for application in polymer electrolyte membrane fuel cells.
\end{abstract}

(c) 2015, Dalian Institute of Chemical Physics, Chinese Academy of Sciences. Published by Elsevier B.V. All rights reserved.

\section{Introduction}

Polymer electrolyte membrane fuel cells (PEMFCs) have been considered as an environmentally friendly solution for automotive, backup, and residential power needs. However, PEMFCs are yet to be implemented on a commercial scale. One of the most important factors preventing their commercial implementation is the severe degradation of the traditional $\mathrm{Pt} / \mathrm{C}$ catalyst employed in PEMFCs. For example, amorphous carbon, which is a commonly used carbon support, is susceptible to corrosive conditions [1] including high water content, low pH $(<1)$, relatively high temperatures $\left(\sim 50-90{ }^{\circ} \mathrm{C}\right)$, high potentials $(\sim 0.6-1.0 \mathrm{~V})$, and high oxygen concentration. The corrosion of the carbon support subsequently leads to the detachment of noble metal nanoparticles (NPs) from the support, resulting in aggregation of noble metal PNs, and then the catalytic activity decreases. Furthermore, oxidation of carbon can change the surface hydrophobicity of the support that can hinder gas transport [2].

The following two strategies can be used to mitigate carbon corrosion: (1) graphitization of carbon black and (2) alternative use of a more stable carbon support. Graphitization of carbon plays an important role in improving the electrochemical stability of the support [3]. Higher amounts of graphitic carbon lead to reduction of defect sites on the carbon structure where carbon oxidation occurs [4]. Graphitization can be achieved by heating carbon materials in protective gas at a high temperature $\left(\geq 1600^{\circ} \mathrm{C}\right)[5,6]$. Graphitization affords the fabrication of materials with high resistance to oxidation and corrosion but with reduced numbers of surface oxygen-containing groups. The latter will accordingly affect metal deposition on the graphitized carbon support [7]. The second strategy to allevi-

\footnotetext{
* Corresponding author. Tel: +86-27-87651837; Fax: +86-27-87879468; E-mail: msc@whut.edu.cn This work was supported by the National Natural Science Foundation of China (51372186), the National Basic Research Program of China (973 Program, 2012CB215504), and the Natural Science Foundation of Hubei Province of China (2013CFA082). 
ating carbon corrosion involves the use of carbon supports with higher stability. Recently, graphene nanosheets (GNS), as two-dimensional layers of $s p^{2}$-bonded carbon, have attracted considerable attention owing to their high surface area, remarkable mechanical stiffness, excellent conductivity, and chemical and electrochemical stabilities [8-10] for application in catalyst supports $[11,12]$. However, GNS tend to agglomerate or restack through van der Waals interactions $[9,10]$, considerably lowering the surface area and limiting permeation of the electrolyte between the graphene layers, consequently decreasing the active surface area. These severely restrict the application of GNS [13-15]. Many attempts have been made to inhibit the restacking of GNS through surface functionalization [16-18], electrostatic stabilization [19], and synthesis of graphene composites consisting of secondary building blocks such as carbon black, carbon nanotube, and conductive nano ceramic $[13,14,20]$. Recently, our group reported a facile method to prepare graphene from $a-\mathrm{Si}_{1-x} \mathrm{C}_{x}$ or a-Ti ${ }_{1-x} \mathrm{C}_{x}$ nanofilms using a chlorination method under mild processing conditions [21,22]. As reported, graphene can exist as graphene-amorphous carbon (GNS@a-C) core-shell structures, which can afford increased corrosion resistance for high electrochemical performance [21].

Herein, for the first time, we report a core-shell GNS@a-C composite prepared by a chlorination method and used it as a support of Pt NPs for oxygen reduction reaction (ORR). The core-shell structure not only inhibits the restacking of GNS mentioned earlier, but also restricts the corrosion of the amorphous carbon core under the harsh operating conditions typically used in PEMFCs. Comparison between the current Pt/GNS@a-C catalyst and the commercial Pt/C catalyst shows that the former has a good catalytic activity and a remarkably high stability.

\section{Experimental}

\subsection{Preparation of core-shell GNS@a-C composites and Pt/GNS@a-C catalysts}

Silicon carbide ( $\mathrm{SiC}$ ) samples (where the shell and core is amorphous and crystalline $\mathrm{SiC}$, respectively) with Nano-shells/ films bought from Kaier Nano Co. and used as received were placed in a horizontal hot-wall tubular flow reactor operating at ambient pressures. Then, the reactor was heated to $800{ }^{\circ} \mathrm{C}$ under pure $\mathrm{He}$ and subsequently exposed to a $\mathrm{He} / \mathrm{Cl}_{2}$ atmosphere for $1 \mathrm{~h}$. The reaction was stopped by flushing the reactor with pure $\mathrm{He}$ gas at $800{ }^{\circ} \mathrm{C}$ for $1 \mathrm{~h}$ to remove residual $\mathrm{Cl}_{2}$ and by-products. The furnace was cooled to $25^{\circ} \mathrm{C}$ under pure $\mathrm{He}$, and then the GNS@a-C was obtained.

$\mathrm{H}_{2} \mathrm{PtCl}_{6} \cdot 6 \mathrm{H}_{2} \mathrm{O}$ (Sinopharm Chemical Reagent Co., Ltd.) solution, which was used as a Pt precursor, was added dropwise to the GNS@a-C suspension under vigorous stirring. The pH of the solution was adjusted to $10-12$ using $1.0 \mathrm{~mol} / \mathrm{L} \mathrm{NaOH}$ aqueous solution, and then the mixture was heated under reflux at 150 ${ }^{\circ} \mathrm{C}$ for 3-4 h to ensure complete formation of Pt NPs. Following stirring overnight, the mixture was filtered and washed with de-ionized water. The obtained catalyst was dried in a vacuum oven at $80{ }^{\circ} \mathrm{C}$ for $8 \mathrm{~h}$. For comparison purposes, a commercial $\mathrm{Pt} / \mathrm{C}$ catalyst (20 wt \% Pt supported on carbon black) was purchased from Johnson Matthey.

\subsection{Characterization}

Morphologies of the support and catalyst were analyzed on a JEOL 2100 high-resolution transmission electron microscope (HRTEM), operating at $10 \mathrm{kV}$. Raman spectroscopy was performed on a Renishaw using Ar ion laser with an excitation wavelength of $514.5 \mathrm{~nm}$. X-ray diffraction (XRD) was performed on a Rigaku X-ray diffractometer equipped with a $\mathrm{Cu} K_{\alpha}$ radiation source. XRD patterns were collected using a step of $0.01^{\circ}$ and a count time of $2 \mathrm{~s}$ per step within a $2 \theta$ range of $10^{\circ}-90^{\circ}$.

Electrochemical studies were conducted using a computercontrolled Autolab PGSTAT 30 potentiostat (Eco Chemie B.V, Holland) with a three-electrode cell setup. A saturated calomel electrode was used as the reference electrode and platinum wire was used as the counter electrode. However, in this paper, all potentials are expressed on the scale of the reversible hydrogen electrode (RHE). The electrolyte solution $(0.1 \mathrm{~mol} / \mathrm{L}$ $\mathrm{HClO}_{4}$ ) was purged using high-purity $\mathrm{N}_{2}$ for 30 min prior to any electrochemical measurements. The sample ( $3 \mathrm{mg}$ ) was dispersed in the stock solution $(1000 \mu \mathrm{L})$ that was prepared by mixing isopropanol $(600 \mu \mathrm{L})$ with pure water $(380 \mu \mathrm{L})$ and 5 wt \% Nafion ionomer solution (20 $\mu \mathrm{L}$; DuPont Co., Ltd.). Then, the formed ink was coated on a mirror-polished glassy carbon disk electrode as a working electrode. The electrochemical erosion (ECE) of the support was assessed at a constant potential of $1.2 \mathrm{~V}$ as a function of time to vary the ECE rates. Cyclic voltammograms in the range of $0-1.2 \mathrm{~V}$ were recorded periodically before and after the ECE test at a constant scan rate of 50 $\mathrm{mV} / \mathrm{s}$. An electrochemical-accelerated durability test (ADT) was conducted by cyclic voltammetry (CV) analysis performed at $0.6-1.2 \mathrm{~V}$ for 4000 cycles. CVs were recorded before and after ADT from 0 to $1.2 \mathrm{~V}$ at a scan rate of $50 \mathrm{mV} / \mathrm{s}$. Finally, the ORR activity of the catalysts was assessed in an $\mathrm{O}_{2}$-saturated $0.1 \mathrm{~mol} / \mathrm{L} \mathrm{HClO}_{4}$ solution on a rotating disk electrode system. Polarization curves were obtained at room temperature at a scan rate of $10 \mathrm{mV} / \mathrm{s}$ and a rotation rate of $1600 \mathrm{r} / \mathrm{min}$, recorded from 1.1 to $0.2 \mathrm{~V}$.

\section{Results and discussion}

\subsection{Structural and electrochemical properties of GNS@a-C composites}

As observed in Fig. 1(a), after chlorination, the amorphous carbon NPs were covered with a few layers of GNS, resulting in a core-shell GNS@a-C architecture. Crystal residues of $\beta$-SiC were not observed after chlorination, indicating the near-complete transformation of $\mathrm{SiC}$ into nanoporous carbide- derived carbon (CDC) matrix and graphene shells (Fig. 1(b)). Fig. 2 shows the Raman spectrum of the final silicon carbide-derived carbon (SiC-CDC). The occurrence of a 2D peak and two relatively broad D and G peaks at 1320 and $1580 \mathrm{~cm}^{-1}$ indicates the 

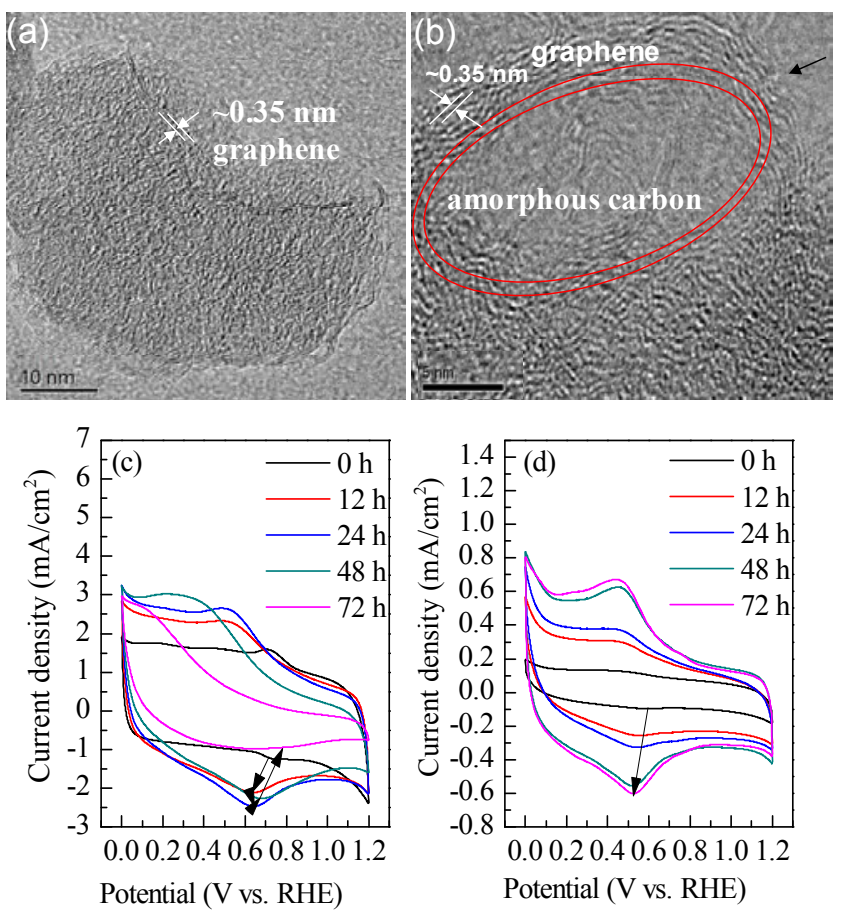

Fig. 1. (a, b) HRTEM images of GNS@a-C.CV plots of GNS@a-C NPs (c) and commercial carbon black (Vulcan XC-72) (d) recorded at $1.2 \mathrm{~V}$ (vs. RHE) as a function of time $\left(0.1 \mathrm{~mol} / \mathrm{L} \mathrm{HClO}_{4}\right.$, scan rate: $\left.50 \mathrm{mV} / \mathrm{s}\right)$ for electrochemical erosion evaluation.

presence of ordered graphitic domains in the a-Si ${ }_{1-x} \mathrm{C}_{x}$ network $[23,24]$, thereby confirming the successful transformation of a-Si $1_{1-x} \mathrm{C}_{x}$ nanoshell on the crystalline SiC NPs into graphene nanoshell. The D band was associated with the presence of defects and staging disorder of graphene and amorphous carbon, and the $\mathrm{G}$ band could be used to investigate the degree of graphitization. As noted in the following discussion, the presence of defects on graphene is conducive to the adsorption of $\mathrm{Pt}$ NPs on the support. Therefore, $a-\mathrm{Si}_{1-x} \mathrm{C}_{x}$ nanoshells were successfully converted into graphene on surfaces of $\beta$-SiC NPs by chlorination, while the $\beta$-SiC core was converted into amorphous carbon.

ECE test was conducted to investigate the stability of GNS@a-C. The results were consistent with that from our previous work [21]. Fig. 1(c) and (d) present the CV curves of GNS@a-C and commercial Vulcan XC-72 carbon, respectively. The potential window between 0.3 and $0.8 \mathrm{~V}$ is an indicator of capacitive current, which depends on the electrochemically accessible area for diffusion of the electrolyte to the internal micropores of the carbon matrix. Relative to XC-72 carbon black, GNS@a-C shows a considerably higher electric doublelayer capacitance, indicative of a higher specific surface area and greater accessibility to the electrolyte and charged ions. For both samples, the peaks between 0.6 and $0.8 \mathrm{~V}$ were attributed to the oxidation-reduction of graphene that became more prominent with increasing ECE treatment times up to $24 \mathrm{~h}$. The increase in the peak intensity can be ascribed to the presence of surface defects that aggravated the corrosion of carbon. After $24 \mathrm{~h}$, the oxidation peak intensity of XC-72 increased with time, whereas that of GNS@a-C decreased. This finding sug-

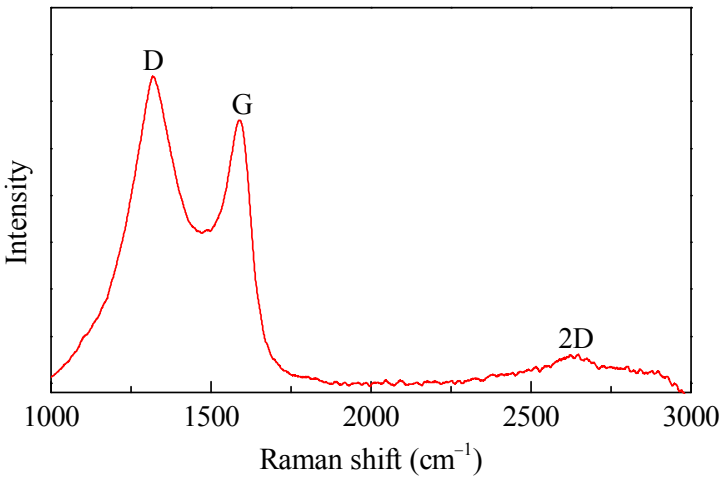

Fig. 2. Raman spectrum of a-C@GNS NPs.

gests that GNS@a-C features higher corrosion resistance and improved electrochemical stability owing to the presence of graphene layers that prevents corrosion of amorphous carbon.

\subsection{Structural and electrochemical properties of Pt/GNS@a-C catalysts}

Powder XRD analysis (Fig. 3) was conducted to compare the structures of GNS@a-C, XC-72, commercial Pt/C, and Pt/ GNS@a-C. The peak at $24.5^{\circ}$ was attributed to the (002) carbon plane of XC-72. In contrast, the (002) peak of GNS@a-C shifted to a lower angle $\left(21.5^{\circ}\right)$ relative to that of XC-72 which could be attributed to the synergetic effect between graphene and amorphous carbon. Following chlorination, distinct crystalline SiC residues or crystalline graphite was not observed, indicating a near-complete transformation of $\beta$-SiC into carbon including amorphous carbon and graphene. The peaks at $2 \theta=30^{\circ}-90^{\circ}$ were indexed to Pt crystals with face-centered cubic (fcc) structures. The peaks at $39.7^{\circ}, 46.5^{\circ}, 67.7^{\circ}$, and $81.4^{\circ}$ were assigned to the (111), (200), (220), and (311) planes of Pt, respectively.

Fig. 4 shows the microstructures of Pt/GNS@a-C and Pt/C catalysts. The lattice planes of Pt/GNS@a-C with spacing of 0.35 and $0.22 \mathrm{~nm}$ were attributed to graphene and Pt (111), respectively. Additionally, Fig. 4(a) and (c) (inset) show the particle size histograms of the catalyst samples as determined from

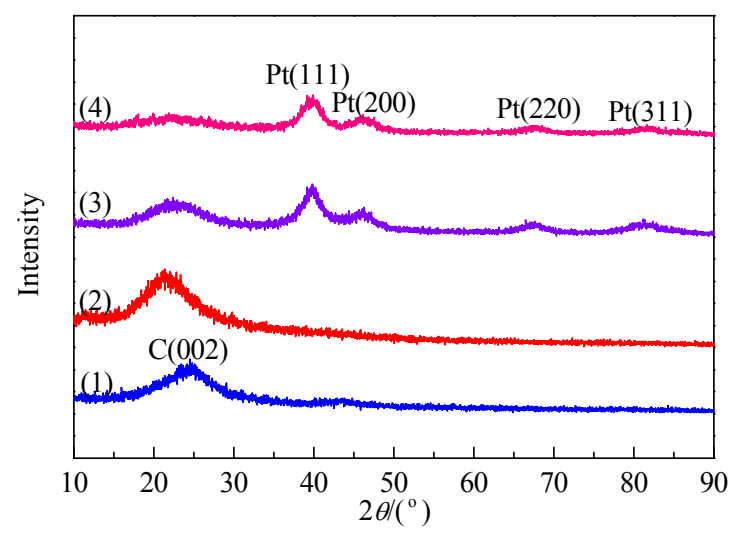

Fig. 3. XRD patterns of XC-72 (1), GNS@a-C (2), Pt/C (3), and Pt/GNS@a-C (4). 


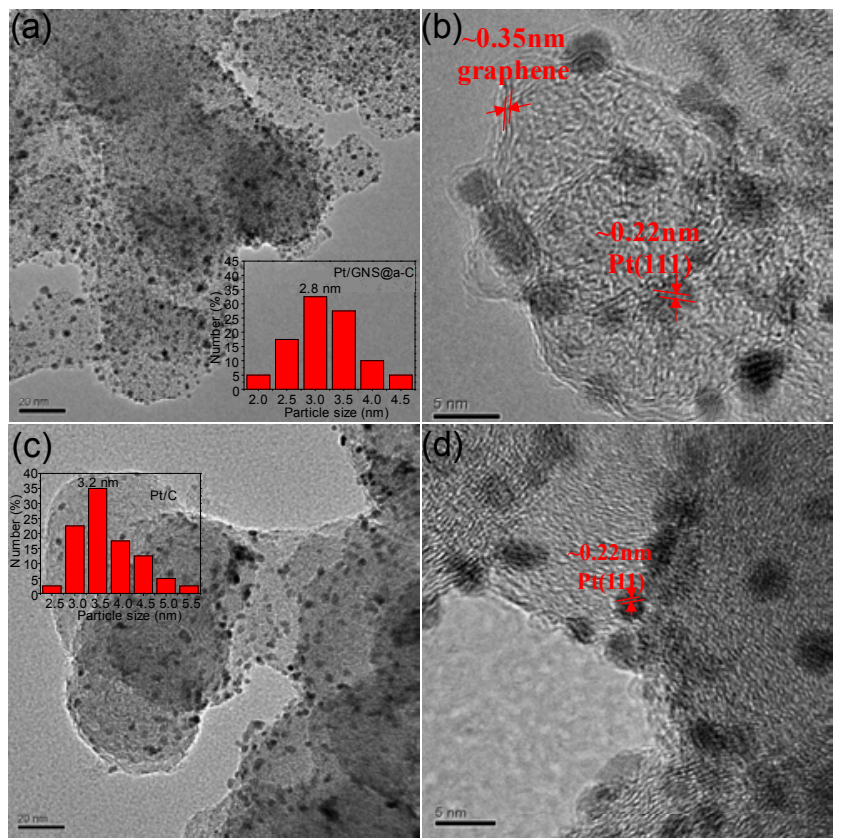

Fig. 4. TEM images of Pt NPs supported on GNS@a-C (a, b) and XC-72 (c, d).

TEM images. Commercial Pt/C catalyst sample (Fig. 4(c) and (d)) featured Pt NPs with an average size of $3.2 \mathrm{~nm}$; some areas featuring aggregated Pt NPs were additionally present, revealing the inhomogeneous distribution of the catalyst particles. In contrast, Pt NPs were well dispersed on GNS (Pt/GNS@a-C) with an average diameter of $2.8 \mathrm{~nm}$ and a very narrow particle size distribution. The surface defects on GNS served as anchoring sites for the Pt precursor to prevent aggregation of Pt NPs. Smaller catalyst particles are believed to display better catalytic activities relative to larger catalyst particles introduced at a given content.

Fig. 5 shows CV curves of both catalysts recorded at room temperature. All voltammograms display a two-peak reduction-oxidation/adsorption-desorption feature. The first peak at 0.04-0.3 V was attributed to the adsorption and desorption of hydrogen on $\mathrm{Pt}$, and the second peak at $0.5-1.2 \mathrm{~V}$ was ascribed to the oxidation and reduction of Pt metal. The electrochemical specific area (ECSA) of the catalyst samples was calculated by measuring the charge collected within the hydrogen adsorption-desorption region following double-layer correction and assuming a value of $210 \mu \mathrm{C} / \mathrm{cm}^{2}$ for adsorption onto a hydrogen monolayer [25,26]. As determined in Fig. 5(a), the ECSA of Pt/GNS@a-C (90.1 m²/g) was higher than that of Pt/C (79.2 $\mathrm{m}^{2} / \mathrm{g}$ ). Based on the polarization curves for ORR of these catalysts in Fig. 5(b), Pt/GNS@a-C featured a similar half-wave potential $(0.83 \mathrm{~V})$ to that of Pt/C (0.81 V). Diffusion-limiting currents were obtained in the potential region below $0.6 \mathrm{~V}$, whereas a mixed kinetic-diffusion control region was observed between 0.7 and $0.9 \mathrm{~V}$. The kinetic current was calculated from the ORR polarization curve at $0.9 \mathrm{~V}$ vs. RHE according to the Koutecky-Levich equation [27]. The mass activity of Pt/GNS@ a-C $(0.121 \mathrm{~A} / \mathrm{mg})$ was nearly twice as high as that of $\mathrm{Pt} / \mathrm{C}$ $(0.064 \mathrm{~A} / \mathrm{mg})$, demonstrating the higher ORR activity of
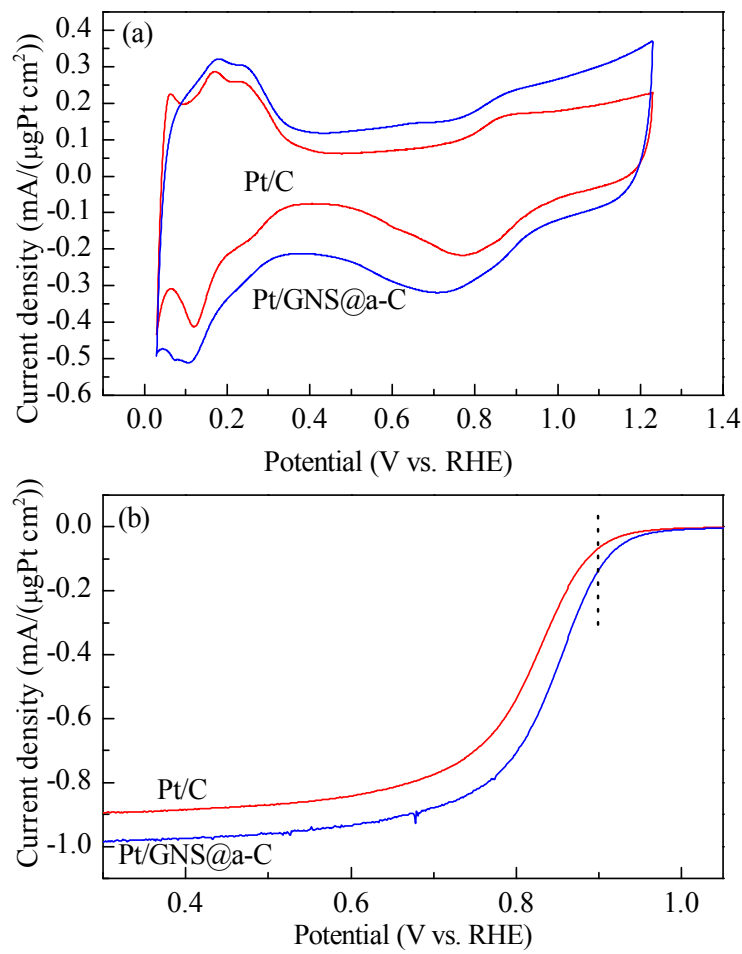

Fig. 5. CV curves of Pt/C and Pt/GNS@a-C (a); Current-potential-polarized curves for ORR (b).

Pt/GNS@a-C compared with that of Pt/C. The improved ECSA and ORR activity could be attributed to the optimized dispersion and size distribution of Pt NPs, and the good electrical conductivity of GNS.

As shown in Fig. 6(a) and (b), both catalysts displayed a decrease in the hydrogen adsorption region following ADT. The retained ECSA, as normalized with the initial ECSA, was plotted as a function of cycle number in Fig. 6(c). After 4000 cycles, $53 \%$ of the initial ECSA of Pt/GNS@a-C was maintained, whereas only $35 \%$ of the initial ECSA was preserved in $\mathrm{Pt} / \mathrm{C}$, thereby demonstrating that Pt deposited on GNS@a-C is considerably more stable than that deposited on carbon under the same testing conditions. The ORR activities of Pt/GNS@a-C and Pt/C before and after ADT are shown in Fig. 6(d). After 4000 cycles, Pt/C displayed $91 \mathrm{mV}$ negative shift of the half- wave potential. In contrast, Pt/GNS@a-C only displayed a 31mV negative shift. The mass activity of $\mathrm{Pt} / \mathrm{C}$ changed from 0.064 to $0.010 \mathrm{~A} / \mathrm{mg}$, corresponding to a decrease of $84.4 \%$. In contrast, the mass activity of Pt/GNS@a-C changed by only 66.7\%.

To further substantiate the difference in degradation between Pt/GNS@a-C and Pt/C, both catalysts were investigated by HRTEM after ADT. Fig. 7 shows the TEM images of the catalysts and the associated Pt size histograms. Slight agglomeration of the Pt NPs was observed for Pt/GNS@a-C that displayed an increased average particle size from 2.8 to $4.8 \mathrm{~nm}$ following ADT (Fig. 7(a) and (c)). By contrast, more severe agglomeration of the Pt NPs was observed for Pt/C after ADT (Fig. 7(b)), and the mean size increased to $5.2 \mathrm{~nm}$ after the potential cycling test (Fig. 7(d)). The high stability of Pt/GNS@a-C relative to that of $\mathrm{Pt} / \mathrm{C}$ demonstrates that the graphene layer is effective in 

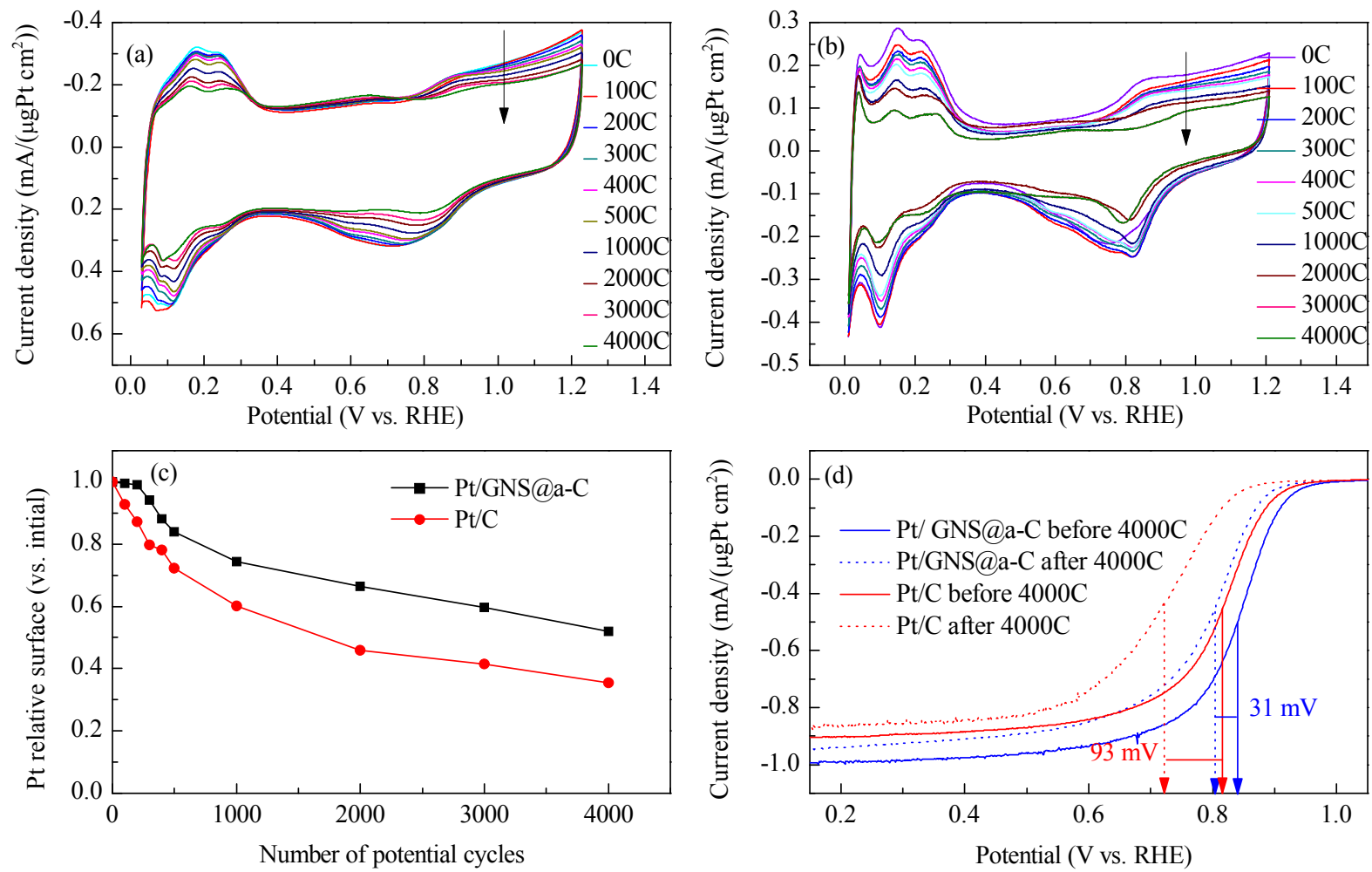

Fig. 6. CV curves of Pt/GNS@a-C (a) and Pt/C catalysts (b) before and after cycling; Variation in ECSA, related to the Pt catalytic surface area, as a function of the cycle number (c); ORR on Pt/GNS@a-C and Pt/C before and after $4000 \mathrm{cycles}$ at $1600 \mathrm{r} / \mathrm{min}(0.1 \mathrm{~mol} / \mathrm{L} \mathrm{HClO} 4$, scan rate $10 \mathrm{mV} / \mathrm{s}$ ) (d).
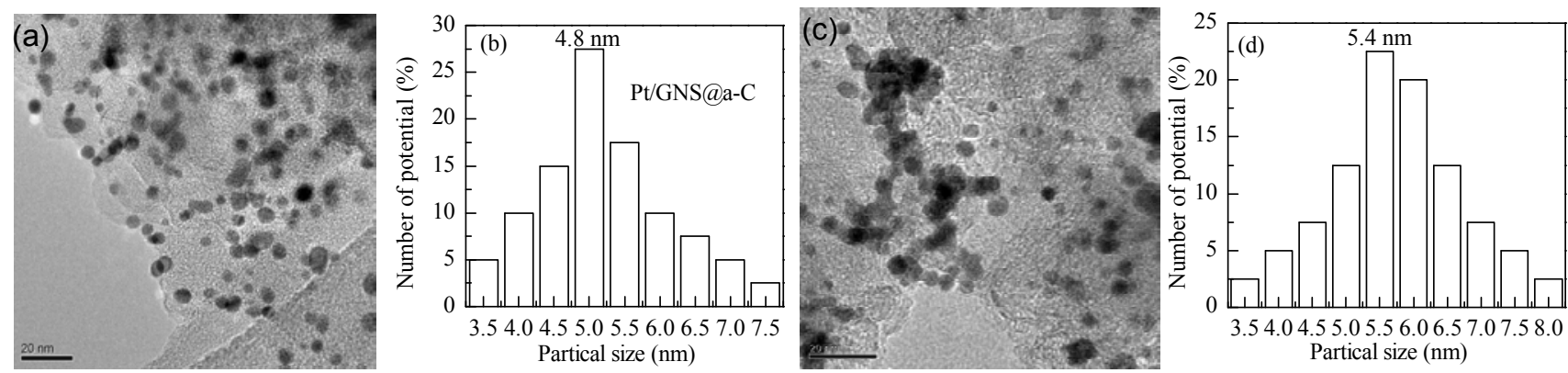

Fig. 7. HRTEM images of Pt/GNS@a-C (a) and Pt/C (c) catalysts after ADT; Associated Pt particle size distributions of Pt/GNS@a-C (b) and Pt/C (d) catalysts.

inhibiting the migration and aggregation of Pt NPs, and increasing the resistance of the support to electrochemical corrosion. However, for $\mathrm{Pt} / \mathrm{C}$, the migration and agglomeration of $\mathrm{Pt}$ NPs on the surface of carbon black are predominantly caused by the corrosion of carbon supports and the Ostwald ripening of Pt NPs that lowers the electrochemical activity of the catalyst [27].

\section{Conclusions}

Core-shell GNS@a-C composites were successfully synthesized by a chlorination method and used as the support for Pt nanoparticles. The Pt/GNS@a-C catalyst displayed significantly enhanced activity and stability relative to the commercial $\mathrm{Pt} / \mathrm{C}$ catalyst. The improved activity was attributed to the good conductivity of graphene that was also effective in inhibiting migration and aggregation of Pt nanoparticles by covering the amorphous carbon core, as well as protecting the carbon from chemical and electrochemical corrosion. The present findings demonstrated the GNS@a-C composite as a highly efficient catalyst support possesses great potential application in fuel cells and other industrial fields.

\section{References}

[1] Kinoshita K. Carbon: Electrochemical and Physicochemical Properties. New York: wiley, 1988

[2] Yu X W, Ye S Y.J Power Sources, 2007, 172: 133

[3] Stevens D A, Hicks M T, Haugen G M, Dahn J R. J Electrochem Soc, 2005, 152: A2309

[4] Shao Y Y, Yin G P, Zhang J, Gao Y Z. Electrochim Acta, 2006, 51: 5853

[5] Coloma F, Sepulvedaescribano A, Rodriguezreinoso F. J Catal, 1995, 154:299

[6] Bom D, Andrews R, Jacques D, Anthony J, Chen B, Meier M S, Sele- 


\title{
Graphical Abstract
}

Chin. J. Catal., 2015, 36: 490-495 doi: 10.1016/S1872-2067(14)60211-4

\section{Core-shell graphene@amorphous carbon composites supported platinum} catalysts for oxygen reduction reaction

Hui Wu, Tao Peng, Zongkui Kou, Jian Zhang, Kun Cheng, Daping He, Mu Pan, Shichun Mu* Wuhan University of Technology

Core-shell graphene nanosheets@amorphous carbon (GNS@a-C) composite, as a highly efficient catalyst support, displays excellent oxygen reduction reaction activity and high electrochemical stability.

gue J P. Nano Lett, 2002, 2: 615

[7] He C Z, Desai S, Brown G, Bollepalli S. Electrochem Soc interface, 2005, 14(3): 41

[8] Geim A K, Novoselov K S. Nat Mater, 2007, 6: 183

[9] Li D, Muller M B, Gilje S, Kaner R B, Wallace G G. Nat Nanotechnol, 2008, 3: 101

[10] Stankovich S, Dikin D A, Dommett G H B, Kohlhaas K M, Zimney E J, Stach E A, Piner R D, Nguyen S T, Ruoff R S. Nature, 2006, 442: 282

[11] He D P, Cheng K, Peng T, Pan M, Mu S C. J Mater Chem A, 2013, 1: 2126

[12] Wu P, Lü H F, Peng T, He D P, Mu S C. Sci Rep, 2014, 4: 3968

[13] Zhao X, Hayner C M, Kung M C, Kung H H. ACS Nano, 2011, 5: 8739

[14] Rao C N R, Sood A K, Voggu R, Subrahmanyam K S. J Phys Chem Lett, 2010, 1: 572

[15] Du X S, Yu Z Z, Dasari A, Ma J, Mo M S, Meng Y Z, Mai Y W. Chem Mater, 2008, 20: 2066

[16] Zu S Z, Han B H. J Phys Chem C, 2009, 113: 13651

[17] He D P, Kou Z K, Xiong Y L, Cheng K, Chen X, Pan M, Mu S C. Carbon,
2014, 66: 312

[18] He D P, Cheng K, Li H G, Peng T, Xu F, Mu S C, Pan M. Langmuir, 2012, 28: 3979

[19] Yang X Y, Dou X, Rouhanipour A, Zhi L J, Rader H J, Mullen K. J Am Chem Soc, 2008, 130: 4216

[20] Fan Z J, Yan J, Zhi L J, Zhang Q, Wei T, Feng J, Zhang M L, Qian W Z, Wei F. Adv Mater, 2010, 22: 3723

[21] Peng T, Lv H F, He D P, Pan M, Mu S. C. Sci Rep, 2013, 3: 1148

[22] Peng T, Kou Z K, Wu H, Mu S C. Sci Rep, 2014, 4: 5494

[23] Bullot J, Schmidt M P. Phys Status Solidi B, 1987, 143: 345

[24] Morimoto A, Kataoka T, Kumeda M, Shimizu T. Philos Mag B, 1984, 50: 517

[25] Schmidt T J, Gasteiger H A, Stäb G P, Urban P M, Kolb D M, Behm R J. J Electrochem Soc, 1998, 145: 2354

[26] Colombi Ciacchi L, Pompe W, De Vita A. J Phys Chem B, 2003, 107: 1755

[27] Lim B, Jiang M J, Camargo P H C, Cho E C, Tao J, Lu X M, Zhu Y M, Xia Y N. Science, 2009, 324: 1302

\section{应用于氧还原反应的石墨烯-无定形碳核壳结构复合材料载铂催化剂}

\author{
吴 惠, 彭 榛, 寇宗魊, 张 建, 程 坤, 何大平, 潘 牧, 木士春 * \\ 武汉理工大学材料复合新技术国家重点实验室, 湖北武汉 430070
}

摘要: 采用氯化法制备石墨烯-无定型碳复合材料(GNS@a-C), 并用作质子交换膜燃料电池(PEMFC)氧还原反应Pt催化剂的载体. 结果显示, 所制Pt/GNS@a-C催化剂与传统商业催化剂 $\mathrm{Pt} / \mathrm{C}$ 相比, 有较好的活性和较高的稳定性: 质量活性 $(0.121 \mathrm{~A} / \mathrm{mg})$ 几乎是 $\mathrm{Pt} / \mathrm{C}(0.064 \mathrm{~A} / \mathrm{mg})$ 的两倍. 更重要的是, 该新型催化剂加速 4000 圈后其电化学活性面积保留了最初的 $51 \%$, 与 $\mathrm{Pt} / \mathrm{C}$ 的 $33 \%$ 相比, 前者 有更好的电化学稳定性, 显示它在PEMFC中将具有较好的应用潜力.

关键词: 低温然料电池; 载体; 核壳结构; 氧还原反应

收稿日期: 2014-07-12. 接受日期: 2014-08-22. 出版日期: 2015-04-20.

*通讯联系人. 电话: (027)87651837; 传真: (027)87879468; 电子信箱: msc@whut.edu.cn

基金来源：国家自然科学基金(51372186); 国家重点基础研究发展计划(973计划, 2012CB215504); 湖北省自然基金重点项目(2013CFA082)

本文的英文电子版由Elsevier出版社在ScienceDirect上出版(http://www.sciencedirect.com/science/journal/18722067). 